\begin{tabular}{|l|l|l||}
\hline \multicolumn{2}{|c|}{ PublisherInfo } \\
\hline \hline PublisherName & $:$ & BioMed Central \\
\hline \hline PublisherLocation & $:$ & London \\
\hline \hline PublisherImprintName & $:$ & BioMed Central \\
\hline \hline
\end{tabular}

\title{
Fly immunity
}

\begin{tabular}{|l|l|l||}
\hline \multicolumn{2}{|c|}{ ArticleInfo } \\
\hline \hline ArticleID & $:$ & 4230 \\
\hline \hline ArticleDOI & $:$ & $10.1186 /$ gb-spotlight-20011019-01 \\
\hline \hline ArticleCitationID & $:$ & spotlight-20011019-01 \\
\hline \hline ArticleSequenceNumber & $:$ & 301 \\
\hline \hline ArticleCategory & $:$ & Research news \\
\hline \hline ArticleFirstPage & $:$ & 1 \\
\hline \hline ArticleLastPage & $:$ & 2 \\
\hline \hline & & RegistrationDate : 2001-10-19 \\
ArticleHistory & $:$ & OnlineDate \\
\hline \hline ArticleCopyright & $:$ & BioMed Central Ltd2001 \\
\hline \hline ArticleGrants & $:$ & \\
\hline \hline ArticleContext & $:$ & 130592211 \\
\hline \hline
\end{tabular}




\section{Jonathan B Weitzman}

Email: jonathanweitzman@hotmail.com

Studies of the response to microbial infection in Drosophila have taught us much about the conserved features of the innate immune response. In the October 23 Proceedings of the National Academy of Sciences, Ennio De Gregorio and colleagues at the CNRS Centre de Genetique Moleculaire, Gif-surYvette, France, describe a genome-wide analysis of the Drosophila immune response (Proc Natl Acad Sci USA 2001, 98:12590-12595). They used high-density oligonucleotide microarrays to probe over 13,000 genes following septic injury or natural bacterial infection. They identified about 400 DIRGs, Drosophila immune-regulated genes; 230 were induced and 170 repressed. De Gregorio et al. discuss the relevance of 134 DIRGs that are predicted to play roles in immune recognition, phagocytosis, coagulation, synthesis of antimicrobial peptides and activation of signalling pathways. Study of the large number of DIRGs representing unknown genes will provide new insights into innate immunity in flies and man.

\section{References}

1. Genes that fight infection: what the Drosophila genome says about animal immunity.

2. Proceedings of the National Academy of Sciences, [http://www.pnas.org]

3. Centre de Genetique Moleculaire, [http://www.cgm.cnrs-gif.fr]

4. Genome-wide Gene Expression Patterns of Drosophila in Response to Immune Challenge, [http://www.fruitfly.org/expression/immunity] 